\title{
The Effect of English Language Proficiency Level on Undergraduate Libyan Students' Use of Subject Verb Agreement
}

Eman A. Elmejie ${ }^{1} \quad$ Fatima M. Elzawawi Amel M. Msimeer Faculty of Arts, Misurata University

Received: 15-07- 2021 Accepted: 21-08- 2021 Available Online: 23-08- 2021

https://doi.org/10.36602/faj.2021.n18.05

\section{Abstract}

This study aims to examine the proficiency level of Libyan EFL (English as a Foreign Language) undergraduate students in terms of the types of subject-verb agreement errors they commit. It also attempts to identify, analyze and categorize the frequency errors related to subject-verb agreement into three categories. These errors are statically analyzed and classified into: subject-verb agreement (SVA) errors with third person singular subjects (TPSS), with third person plural subjects (TPPS), with compound subjects (CS). The participants of this study were 40 intermediate and advanced students whose major is English at the Faculty of Arts in Misurata University, Libya. They were chosen based on their level of English language proficiency during the current study. The data of this study were collected through a written test consisting of six short passages. The results showed that the percentage of errors made by both groups was below 30\% which refers to non-significant differences among the two groups with respect to the SVA errors made by them. Consequently, it can be concluded that language proficiency has little effect on the participants' use of the SVA rule. It was also found that subject-verb agreement errors with (TPPS) were the least frequent, and the most common errors committed were (CS) and (TPSS). This study is important for EFL teachers to be aware of the subject verb agreement errors that their target learners commonly produce. The implications for SLA research and classroom teaching practice are given for foreign language teachers and researchers.

Keywords: Subject Verb Agreement (SVA), Third person Singular Subject (TPSS), Third Person Plural Subject (TPPS).

\footnotetext{
eman.elmejie@art.misuratau.edu.ly ${ }^{1}$
} 
تأثير مستوى كفاءة الطلبة الليبيين الجامعيين الدارسين للغة الانجليزية على استخدامهم لقاعدة تطابق الفعل مع الفاعل

أمل محمد مسيمير

$$
\text { كلية الآداب- جاطمة محمد الزواوي }
$$

إيمان علي الجيعي

\section{ملخص البحث}

تمدف هذه الدراسة إلى اختبار مدى تأثير مستوى كفاءة الطلبة الليبين الجامعيين في استخدام

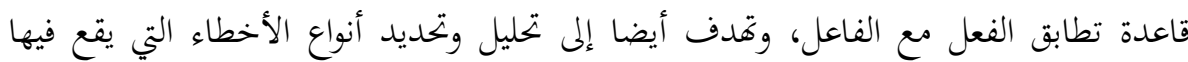
هؤلاء الطلبة والمتعلقة أيضا باتفاق الفعل مع الفاعل أثناء تعلمهم اللغة الإنجليزية كلغة أجنبية.

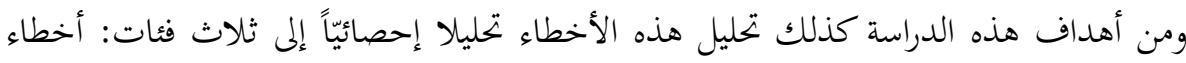

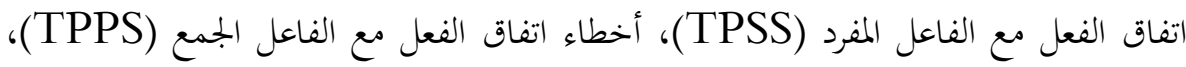

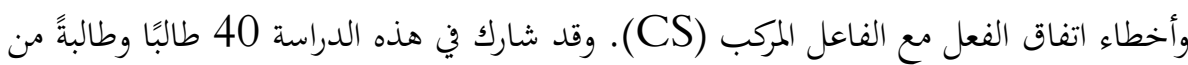
المستويين المتوسط والمتقدم ممن تخصصوا في دراسة اللغة الإنجليزية في كلية الآداب بجامعة مصراتة،

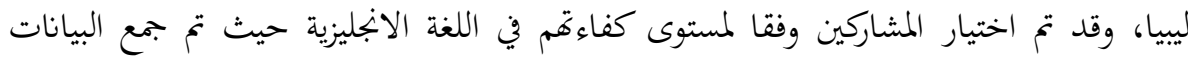
باستخدام اختبار مكوّن من ست فقرات قصيرة، وقد أظهرت نتائج الدراسة أن نسبة الأخطاء

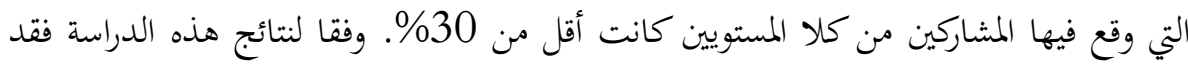

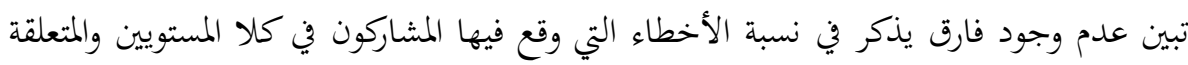

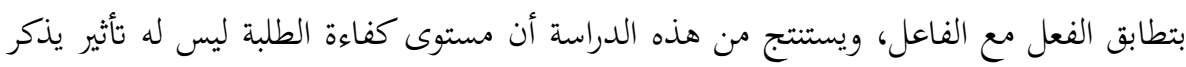

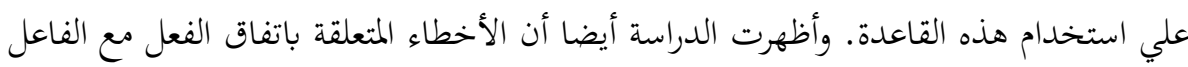

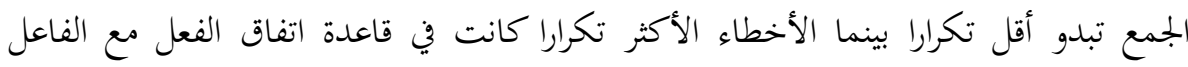

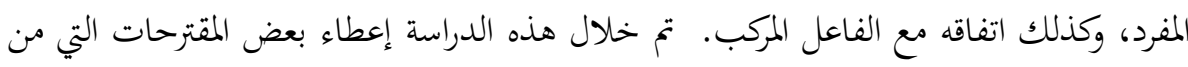
شأها مساعدة كل من معلمي وباحثي اللغة الانجليزية كلغة أجنبية. الكلمات المفتاحية: اتناق الفعل مع الفاعل، الفاعل المفرد للشخص الثالث، الفاعل الجمع لإع لشخص الثالث. 


\section{Introduction}

English is considered to be a foreign language in Libya. Teaching and learning English in Libya have gone through various problematic stages during the 1990s. A few years later, the policy of Libyan educational authorities towards teaching and learning English has totally changed. English has been taught as a compulsory subject at Libyan schools. English, as a foreign language, is only used in certain public and private places such as in schools, universities, some offices, etc. In other words, English is not used in daily communication but it has become the first foreign language, which is used only in those special places (Abdalwahid, 2012).

In learning English, EFL learners are assumed to be able to learn and mange four language skills (listening, reading, writing and speaking) and language elements (phonology, vocabulary, and grammar). Although several changes have been achieved in favor of teaching and learning English in Libya, the objectives have not been yet accomplished (Aldabbus, 2010). It has been noticed that some intermediate and advanced students still face different challenges in mastering and learning the English grammatical rules despite the fact that they have been learning the language for several years. In other words, the acquisition of grammar has become one of the most common issues when learning the English language (Aldabbus, 2010). For example, one of the most discussed questions that is considered an area of difficulty to foreign language learners in different levels is mastering the rules of subject verb agreement (SVA). Although some Libyan studies (Abdalwahid, 2012; Aldabbus, 2010; Hamed, 2014) have investigated different grammatical errors in writing made by EFL Libyan learners, little focus has been noticed on investigating the effect of proficiency level of Libyan EFL students in terms of types of subject-verb agreement. Therefore, this study is essential for EFL teachers to be aware of the SVA type errors the EFL learners regularly commit. The study can also lead them to examine whether the 
proficiency level of the EFL learners can affect mastering SVA rules or not.

\subsection{Research Questions}

The production of SVA in the English language is still understudied. This study aims to answer two research questions which investigate the effect of the language proficiency level on the participants' use of the SVA rule and try to identify the types of SVA errors committed by the Libyan EFL undergraduate students, at the Faculty of Arts in Misurata University. The study deals with the following research questions:

1. Does the level of language proficiency have an effect on Libyan EFL undergraduate students' actual practice of the rules of SVA?

2. What are the types of errors regarding SVA made by EFL Libyan undergraduate students at the Department of English in the Faculty of Arts at Misurata University?

\subsection{Significance of the Study}

This study aims at:

- Examining the proficiency level of Libyan EFL undergraduate students at the Department of English in the Faculty of Arts at Misurata University in terms of the types of SVA errors.

- Identifying, analyzing and categorizing the types of errors of English among the EFL undergraduate Libyan students related to subject-verb agreement according to their proficiency level.

\subsection{Literature Review}

Based on second language acquisition (SLA) studies, the process of English language learning is like any other process of 
learning and acquiring skills which includes making a variety of errors. Many EFL language teachers have been focusing on analyzing, assessing, categorizing and encountering the language learners' errors committed at different proficiency levels for different reasons. EFL Libyan teachers should be able to analyze and identify errors the learners produce at different levels in order to figure out, understand the linguistic causes and reasons for their occurrences and determine what action needs to be taken to minimize these errors. In addition, studying errors can assist EFL teachers to master and introduce the knowledge of learners' language, provide them with information on how the language can be learned and acquired, and present adequate background knowledge about English language (Hamed, 2014).

Several Second Language Acquisition (SLA) researchers have illustrated the concepts and the importance of studying the English grammatical errors. Referring to Corder (1974), studying errors is an important part in learning any language. One of the most challenging errors that EFL learners commit is related to subject verb agreement. Any basic English sentence needs at least a subject and a predicate to be understood and mastered. Regarding the importance of learning and mastering how to match subjects with verbs in English sentences, many second language acquisition (SLA) researchers around the world have been studying subject verb agreement errors made by learners of English. For instance, Sofian and Huran (2018) stated that,

Subject-Verb Agreement (SVA) refers to the rules of grammar in English language where the subject usually agrees or matches with the verb/s used in a sentence. According to this rule of grammar, if the subject is singular, the verb used in that sentence should be singular to agree with it; for the plural subjects, similarly the plural verbs are generally used considering the number of the subject (p.95) 
In addition, Wood (1981) presented that subject verb agreement is related to the matching of subjects and verbs according to their numbers. This means that a singular subject must go with a singular verb form as in 'the girl shouts', and a plural subject must agree with a plural verb form as in 'the girls shout'. Accordingly, SVA is an important element to be mastered by EFL learners at different proficiency levels while learning English language. Aldabbus (2010) goes with Celce-Murcia and Freeman's idea (1999) in which he says that in spite of the early introduction of SVA rules, EFL learners still encounter problems at all proficiency levels.

According to Turkenik (1998), it is important to clarify the rules of subject-verb agreement in order to help EFL learners minimize their SVA errors. The SVA rules are classified into three basic rules: using the main verb of 'verb to be' and 'verb to have' with simple present and simple past tenses, adding the suffix ' $-s$, -es, -ies' in simple present tense, using verb to be (is /are/ was /were) and verb to have (has/have) as the first auxiliary verb with compound tenses. Turkenik added that many EFL learners face struggles in using, mastering and applying these rules in their learning skills although they have been learning English for many years. Correspondingly, Payne (2011), as cited in Pandapatana,(2020), declared an essential point in which he said that:

English is not a list of rules to memorize but it is dynamic, everchanging, and complex to express the kinds of ideas human beings need to express through which understanding the various structures and patterns that the language made up is internalized. Hence, teachers should fully understand the goal is to make the learners realize that language is absorbed comprehensibly (p.130)

Along in the same lines, Alahmadi (2019) stated that making a subject goes along with a verb or vice versa is one of the most 
common problems produced by EFL learners. Although this rule looks easy, many EFL learners, even in advanced levels, may have obstacles to use, manage and apply this rule. According to Alahmadi, there are three types of SVA errors the EFL learners could produce: subjectverb agreement (SVA) errors with (TPSS) such as 'A little girl plays' subject-verb agreement errors with (TPPS) such as 'The children cry', and subject-verb agreement errors with (CS) such as 'Sam and Jack ride their bikes to school'. The findings of Alahmadi 's study (2019) supported the earlier researchers' results which sought to analyze the subject and verb agreement errors made by EFL learners to find solutions and sources of these errors, and take pedagogical precautions towards them.

Quirk and Greenbaum, (1973) stated that there are many struggles faced EFL learners on using, forming, and mastering the SVA rules because of many reasons: some of English learners do not have rules regarding of (SVA) in their first language (L1) and all singular and plural subjects need the same form of verb, and other EFL learners are influenced by their L1 while matching subjects and verbs in simple present and simple past tense. These problems led to the students' unsuccessful mastery of SVA. Quirk and Greenbaum demonstrated that the difficulty is clearly noticed when there are words and phrases interfering between subjects and verbs. For example, 'The words of the song are written by Sam Molar'. The verb 'are' agrees with the subject 'words' not with the word 'song'. In addition, the two researchers displayed that the form of a verb relies on whether the subject of a sentence is a singular or a plural. The distinction between singular and plural appears in present tense sentences, where the (TPSS) has the suffix $-S$ and the (TPPS) has the base form. According to Quirk and Greenbaum 's study (1973) which was supported by Gunawan and his colleagues (2018), EFL learners encountered problems with three types of (SVA) because of some effective sources. The types of SVA errors based on Surface Structure Taxonomy (SST) are omission as in, 'She clearly describe all the 
lessons', addition as in, 'It is has many historical buildings', misinformation as in, 'There are many schools that has a classical architecture', and mis-ordering as in, 'I did not know what was it'. Referring to the causes of these errors, there are some causes that could affect EFL leaners' ability to master the SVA rules. The causes could be the negative language interference, lack of mastery of English grammatical rules, carelessness and translation.

\subsection{Related Studies}

It is important to put lights on some of SLA studies, which have focused on investigating SVA errors that have been made by EFL learners. The errors related to SVA are very common while learning the English language. Abdel-ghani, (1989) focused on studying the SVA errors committed by 90 Jordanian secondary learners, who were from three different proficiency levels, first, second and third level, from five academic secondary schools in Irbid, Jordan. The study showed that there were no considerable differences between the three levels of Jordanian learners with regard to the SVA errors produced by them.

Several scholars have conducted similar studies related to SVA errors. For example, Salebi (2004) examined the grammatical errors of Saudi EFL learners in the fourth and the seventh semesters at the Department of Foreign Languages at King Faisal University. This study aimed to investigate the effect of the English proficiency level of the learners and identify the types of errors 32 Saudi female college learners produced in the two semesters in their writing tasks. The participants joined an error analysis course to learn how to classify, categorize and recognize SVA errors in English. The researcher used a test and students' comments to collect and analyze the data. The results showed that almost $45 \%$ of the participants in the two semesters had a problem with matching the verbs with (TPSS) and (TPPS). Regarding the level of proficiency, the study demonstrated that there are no big differences between the participants in the two 
levels in making SVA errors. The study also clarified that the main reason for these errors was the lack of mastery of English grammatical rules.

Marzuki and Zainal (2004) conducted a study among Malaysian EFL learners from intermediate and advanced levels. The study aimed to examine the SVA errors made by 59 Malaysian learners when writing tasks. The participants were studying at University Teknologi Malaysia. The researchers analyzed the tasks done by the target learners from the Faculty of Science. They were asked to write a task consisting of three to four pages following the instructions given during the class. The findings showed that the Malaysian EFL learners committed different SVA errors. These errors were classified into three types in terms of their proficiency levels: (TPSS), (TPPS) and (CS). The study revealed that the most common error was the disagreement of verbs with compound subjects (CS) registering a total of $70 \%$ for the intermediate participants and $65 \%$ for the advanced learners. According to Marzuki and Zainal 's study, the language proficiency has little effect on the participants' use of the SVA rules.

Wulandari (2005) focused on analyzing and classifying the SVA errors done by 48 fourth and sixth semester participants at Department of English at Muhammadiyah University of Malang, Indonesia. The researcher used a written test to examine the participants. The results of the study displayed that the Indonesian students were unable to master English SVA rules. They were unable to match the subjects with the correct verbs. The study revealed that the most common frequency of error the two level students made was for basic subjectverb agreement error with a percentage $82 \%$. This result proved the same result of Marzuki and Zainal 's study (2004), which showed that the language proficiency has very little effect on the participants' use of the SVA rule.

Regarding to the three types of SVA errors, Zawaherh (2012) aimed to identify the written SVA errors done by 350 students, in the 
tenth grade, who were selected randomly from different levels in different schools in Jordan. The participants were asked to write a descriptive essay about a 'Journey to Jerash' in Jordan. The essays were collected and analyzed to find out the SVA errors. The results demonstrated that the most committed errors were (TPSS) and (TPPS) respectively.

Alahmadi (2019) aimed at examining subject-verb agreement errors made by twenty five female undergraduate learners in the first year at Tiabah University, Saudi Arabia. The participants were from two different levels of English language, intermediate and upperintermediate. Their level was determined by a special test. Error analysis (EA) method was used to analyze, evaluate and classify the errors that appeared in the learners' language. The participants were given eight different topics over two months and asked to write a new essay in an hour. The results revealed that three types of SVA errors were produced by the learners. $72 \%$ of errors were in the verbs not going along with the singular subjects. For instance, 'A teacher give a grammar class every day'. The results also demonstrated that approximately $65 \%$ of the total number of errors were the verbs not matching with the third person plural subjects (TPPS). For example, 'The governments has the right to make decision'. The second common errors were third person singular subjects (TPSS) as in, Sam study hard' while the third common errors were compound subjects (CS) as in 'Jack or his friends run every weekend'. This study showed that language proficiency has no effect on the participants' use of the SVA rule.

\section{Research Methodology}

\subsection{Research Design}

The study applies a quantitative approach to analyze the data using Microsoft Excel (version 2013). Creswell (2007) describes a quantitative approach as a type that requires statistical numbers. 


\subsection{Research Context and Participant}

The participants of the current study were forty Libyan EFL undergraduate students in the Department of English at the Faculty of Arts, Misurata University, Libya. Their native language is Arabic. The participants were chosen based on their level of English language proficiency during the current study. One group (among the other groups in the same semester) which contained twenty students was chosen from two levels. Twenty students were in the third semester, and the other twenty students were enrolled in the eighth semester which is the last stage of the study. The level of the first group was intermediate while that of the second group was advanced. This was determined by tests undertaken by each group during their regular classes, with the permission of their teachers and the participants.

\subsection{Research Instrument}

Data were collected by means of a written test consisting of six short passages. Each verb appearing in these passages was given in two forms in brackets and the task was for the participants to choose the correct form in each case. The test was designed to assess the students' knowledge of the rules for SVA use in English. The test items represented three types of potential SVA error, which were (1) compound subject (CS), (2) third person singular subject (TPSS), and (3) third person plural subject (TPPS). Each error type was tested ten times, giving a total of thirty test items. The different error types were randomly distributed between these items.

\section{Data Analysis and Discussion}

The test results were analyzed by counting the number of incorrect choices produced by the participants while completing the test. These numbers and the percentages of incorrect answers are presented below in tables and bar charts created using Microsoft Excel (version 2013). Table (1) shows the results for the intermediate level learners. 
Table (1): Number of errors made by the intermediate participants in the test.

\begin{tabular}{|c|c|c|c|c|}
\hline Students & $\begin{array}{c}\text { CS } \\
\text { ERROES }\end{array}$ & $\begin{array}{c}\text { TPSS } \\
\text { ERRORS }\end{array}$ & $\begin{array}{c}\text { TPPS } \\
\text { ERRORS }\end{array}$ & $\begin{array}{c}\text { PERCETAGE OF } \\
\text { ERRORS }\end{array}$ \\
\hline 1 & 4 & 2 & 4 & $23.33 \%$ \\
\hline 2 & 4 & 7 & 2 & $43.33 \%$ \\
\hline 3 & 0 & 0 & 0 & $0.00 \%$ \\
\hline 4 & 4 & 1 & 3 & $26.67 \%$ \\
\hline 5 & 2 & 0 & 0 & $6.67 \%$ \\
\hline 6 & 5 & 2 & 2 & $30.00 \%$ \\
\hline 7 & 6 & 5 & 0 & $33.33 \%$ \\
\hline 8 & 2 & 1 & 1 & $13.33 \%$ \\
\hline 9 & 4 & 4 & 0 & $26.67 \%$ \\
\hline 10 & 3 & 3 & 3 & $30.00 \%$ \\
\hline 11 & 6 & 0 & 4 & $33.33 \%$ \\
\hline 13 & 2 & 1 & 0 & $10.00 \%$ \\
\hline 14 & 3 & 6 & 4 & $50.00 \%$ \\
\hline 15 & 6 & 5 & 4 & $40.00 \%$ \\
\hline 16 & 0 & 1 & 1 & $6.67 \%$ \\
\hline \hline 17 & 2 & 6 & 4 & $40.00 \%$ \\
\hline 18 & 5 & 4 & 5 & $46.67 \%$ \\
\hline 19 & 1 & 3 & 4 & $26.67 \%$ \\
\hline 20 & 4 & 4 & 4 & $40.00 \%$ \\
\hline \hline & $30.00 \%$ & $29.20 \%$ & $21.60 \%$ & $26.9 \%$ \\
\hline
\end{tabular}

Table (1): Number of errors made by the intermediate participants in the test.

As can be seen from the data in table (1), the overall percentage of the participants' errors in this group is $26.9 \%$. All the participants' error percentages range between $0 \%$ and $50 \%$. This shows that the participants were able to apply the grammatical structure rules relating 
to subject-verb-agreement correctly. Table (1) shows that $21.60 \%$ of errors were found in students' responses to the third person plural subjects (TPPS) agreeing with the verb. This percentage is the lowest in comparison to the other two types i.e. CS, which was the highest percentage (30\% of errors) and TPSS (29.2\%). This result is different from the findings of other studies such as Zawaherh (2012) and Salebi (2004), where TPSS and TPPS errors were found to be more frequent than CS errors.

When asked to choose the correct form of the verb, nineteen participants were unable to recognize which form agreed with the subject of the sentence. For example, in the sentences '*countries ....(has-have) problems', although the sentence structure is simple and it consists of common and familiar words in English, ten of the participants did not recognize that the plural noun 'countries' requires the third person plural form of the verb, namely 'have'. This finding supports Wulandari 's study (2005), which showed that Indonesian students had difficulties in differentiating between singular and plural verbs as well as singular and plural subjects.

The most problematic type of SVA error was in the case of a compound subject CS. As shown in table (1), the error percentage in this category was $30 \%$. This finding is in line with Marzuki and Zainal 's study (2004) in which CS was found to be the most frequent error. It seems that the Libyan students found difficulty to distinguish between the singular and the plural form of verb, when combined with or separated from the subject in the same sentence. To clarify this, some examples from the test are shown below as follows:

1. The population in some countries .......... (is-are) extremely increased.

2. Both Jack and Mike ........ (has-have) to pass the final exam. 
As shown above, the participants committed SVA errors in both singular and plural. For instance, in the phrase 'the population in some countries', the word 'the population' is a singular subject and therefore requires the singular form of the verb, namely ' $i s$ '. However, thirteen participants have identified the word 'countries' as the subject, since they selected the plural form 'are' as their answer. The second example is a similar case. The subject phrase 'Both Jack and Mike' should be followed by a plural form of the verb, but four participants incorrectly chose the singular form. The same idea has been raised by Quirk \& Greenbaum (1973) who said that ESL learners usually have difficulty to use SVA correctly, especially when the subject is more than one word.

A similar data analysis procedure to that used with the intermediate group was applied to the data provided by the advanced proficiency group.

As can be seen in table (2), the overall percentages for each error type achieved in the target test were very similar to the results from the intermediate level participants.

As shown in table 2, the third person plural subject TPPS got the lowest percentage of errors, while the frequency of the other two types of errors i.e. CS and TPSS was almost the same (29.6\%) for TPSS and $28.0 \%$ for CS. With regard to the TPPS type, participants $6,9,10,11$ and 15 answered correctly throughout, always choosing the correct form of the verb to agree with the subject, whereas the other participants made between 1 and 5 errors out of ten. Student 18 made a total of 7 errors in this category, which makes his score 3 out of 10 . 
Table (2): Number of errors made by the advanced participants in the test

\begin{tabular}{|c|c|c|c|c|}
\hline Students & $\begin{array}{c}\text { CS } \\
\text { ERROES }\end{array}$ & $\begin{array}{c}\text { TPSS } \\
\text { ERRORS }\end{array}$ & $\begin{array}{c}\text { TPPS } \\
\text { ERRORS }\end{array}$ & $\begin{array}{c}\text { PERCETAGE OF } \\
\text { ERRORS }\end{array}$ \\
\hline 1 & 3 & 6 & 4 & $23.33 \%$ \\
\hline 2 & 5 & 2 & $\overline{11}$ & $43.33 \%$ \\
\hline 3 & 1 & 4 & 4 & $0.00 \%$ \\
\hline 4 & 5 & $\overline{5}$ & 3 & $26.67 \%$ \\
\hline$\overline{5}$ & $\overline{4}$ & 3 & $\overline{1}$ & $6.67 \%$ \\
\hline 6 & 3 & 2 & $\mathbf{0}$ & $30.00 \%$ \\
\hline 7 & 5 & 2 & 3 & $33.33 \%$ \\
\hline 8 & 2 & 7 & 2 & $13.33 \%$ \\
\hline 9 & $\overline{1}$ & 2 & $\overline{0}$ & $26.67 \%$ \\
\hline 10 & 2 & 2 & 0 & $30.00 \%$ \\
\hline 11 & $\overline{2}$ & 3 & $\overline{\overline{0}}$ & $33.33 \%$ \\
\hline 12 & 2 & 2 & 1 & $10.00 \%$ \\
\hline 13 & $\overline{8}$ & $\overline{6}$ & $\overline{4}$ & $50.00 \%$ \\
\hline 14 & 6 & $\overline{66}$ & 5 & $40.00 \%$ \\
\hline 15 & 4 & 3 & 0 & $50.00 \%$ \\
\hline 16 & $\overline{3}$ & $\overline{4}$ & $\overline{2}$ & $46.67 \%$ \\
\hline 17 & 3 & $\overline{4}$ & $\overline{5}$ & $40.00 \%$ \\
\hline 18 & 2 & 4 & 7 & $46.67 \%$ \\
\hline 19 & 5 & 3 & 6 & $26.67 \%$ \\
\hline 20 & 4 & 4 & 4 & $40.00 \%$ \\
\hline & $28.00 \%$ & $29.60 \%$ & $20.80 \%$ & $26.1 \%$ \\
\hline
\end{tabular}


Most of the errors in the advanced proficiency group were recorded for the third person singular subject, such as 'My teacher ...... (is-are) funny'. 'He.....(like, likes) to tell jokes'. Even though the sentences seemed to have simple words, six participants failed to select the correct form of the verb to agree with the subject. (CS) is considered problematic for both language proficiency groups.

Figure (1): The comparison between two levels of the participants in terms of (CS), (TPSS) and (TPPS).

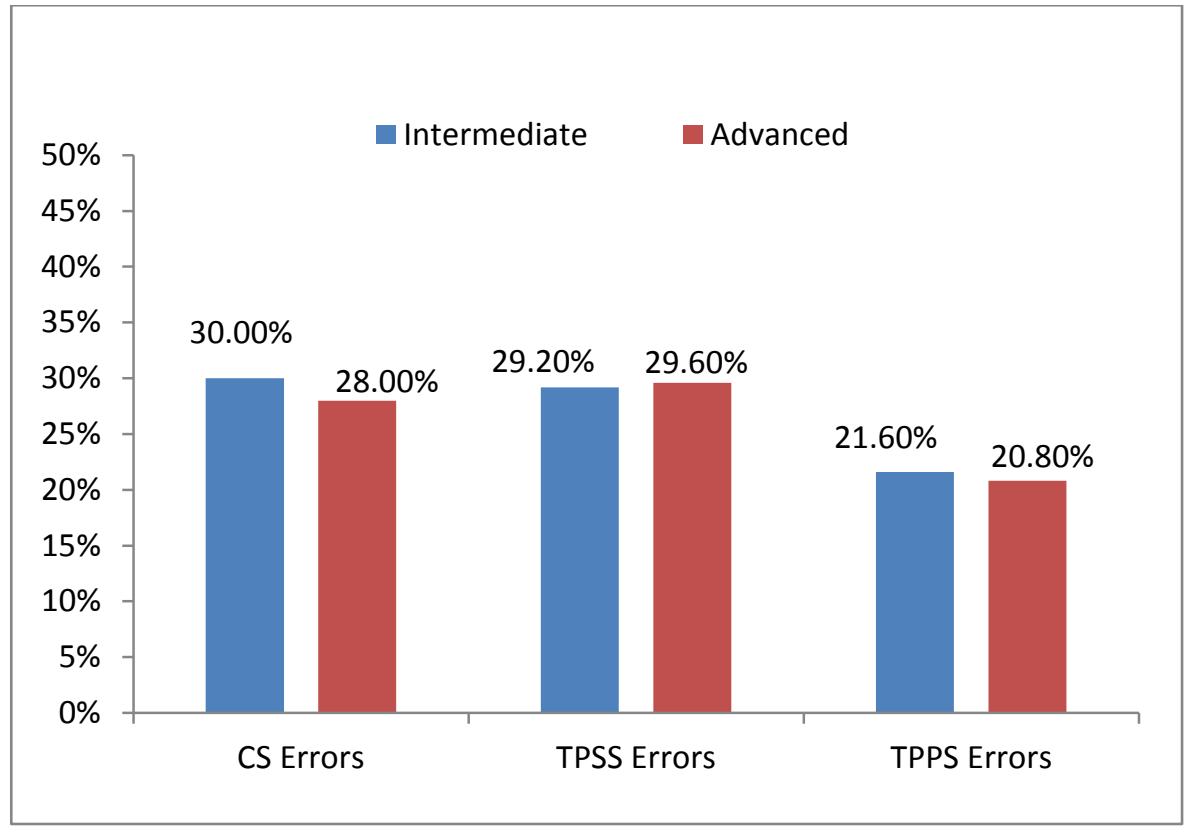

Based on the arguments about whether English language proficiency level can affect the Libyan students' use of subject-verbagreement or not, figure (1) shows a comparison between the two groups of participants (intermediate and advanced) regarding the three error types of SVA. i.e. CS, TPSS and TPPS, discussed in this study.

It appears that language proficiency has little effect on the participants' use of the SVA rule. This finding is in line with Abdelghani 's study (1989), which showed that few differences were 
observed among Jordanian learners at three different levels in terms of SVA errors made by them.

The overall percentages of errors for each error type made by the participants in the two groups were very similar. The intermediate participants had $26.9 \%$ of errors overall, while the group of the advanced participants had $26.1 \%$. This finding shows that the ability of all the participants to recognize the correct forms of subject-verb agreement is quite good. A very high percentage of the participants (more than $70 \%$ at both levels) chose the correct answers in the test. The results of this research suggest that participants' proficiency in English is not a significant factor in their ability to apply SVA rules, and that they made relatively few errors in distinguishing between correct and incorrect forms, this may be considered a surprising outcome given the fact that Libyan students have little exposure to English outside of the language classroom.

\section{Conclusion and Recommendations}

This study investigated the effect of the level of language proficiency of two groups of Libyan students on their ability to apply SVA rules in English. This is one of the grammatical problems that Libyan students encounter when learning English as a foreign language. The findings reveal that Libyan EFL learners with different proficiency levels face some struggles in applying, mastering and following the rules of SVA.

The data of this study was analyzed based on three types of grammatical SVA errors, which are CS, TPSS, and TPPS. It was shown that a number of participants made subject-verb-agreement errors related to each subject type, and that errors in the CS area were the most frequent. This might be because in such cases the sentence subject consists of more than one word. However, subject-verb agreement in the case of TPSS also seems to be problematic for both intermediate and advanced participants. Errors were committed least frequently in the case of TPPS. 
It is noteworthy that even though some subject verb agreement errors were made by the participants of the two groups; the overall percentage of errors is quite low, compared to the number of correct answers. The results show that the percentage of errors made by both groups was below 30\%. Based on the fact that there was very little difference in the percentage of errors made by both groups, it can be concluded that language proficiency has little effect on the participants' use of the SVA rule. This finding supports Alahamadi (2019) and Wulandari (2005)'s studies, which found that no considerable differences between two different levels of language proficiency in terms of applying SVA rule.

Although the rules of SVA are taught at a very early stage of learning English, they can be difficult for learners to acquire and apply correctly since errors in the area of SVA are not significant for the communication of meaning. In other words, a learner who writes ' $M y$ teacher like to tell jokes' or 'Both Jack and Mike has' will not be misunderstood as a consequence of such errors; the meaning is still clear and unaffected by the error. For this reason. it is recommended that classroom practice should not focus too strongly on formally teaching the rules of SVA agreement, which were already covered at a lower level, but should proceed by highlighting errors when they occur during language practice, especially in learners' writing. For the sake of fluency in speaking, it may be more beneficial to the learners' language development to ignore most SVA errors as they rarely lead to any problems of communication. It is also recommended that the EFL teachers may use and comprise the differences between the grammatical rules so that learners will be aware about such differences and they may minimize producing such errors. 


\section{References}

Abdel-ghani, M. A. (1989). An Analysis of Errors Made by Jordanian Secondary Male Students in Their Learning of English Passive Constructions - Unpublished Master's Thesis, Yarmulke University, Irbid, Jordan.

Abdalwahid, A. S. A. (2012). Cohesion features in argumentative essays written by Libyan tertiary EFL students (Arabicspeakers) at Omar Al-Mukhtar University in Libya. Unpublished Master Thesis. Griffith University, Queensland, Australia.

Alahmadi, N. (2019). A Study of Grammatical Errors of Subject Verb Agreement in Writing Made by Saudi Learners. International Journal of English Language and Linguistics Research, 7(6), $48-59$.

Aldabbus, S, (2010). Nature of classroom interaction in some Libyan primary schools. Published paper. ELTEX Conference AlFateh University.

Celce-Murcia, M., \& Larsen-Freeman, D. (1999). The Grammar Book: An ESL/EFL Teacher's Course (2nd ed.). Boston, MA: Heinle \& Heinle Publishers.

Corder, S. P. (1974). Error Analysis: Perspectives on second language acquisition. London: Longman.

Creswell, J. W. (2007). Qualitative Inquiry and Research Design: Choosing among five approaches ( $2^{\text {nd }}$ ed.). Sage Publications, Inc.

Gunawan, R., Indah, R. L., \& Mulyani, P. (2018). Error Analysis of Subject-Verb Agreement Made by Students in Meurandeh Langsa. LANGUAGE LITERACY: Journal of Linguistics, Literature, and Language Teaching, 2(2), 157. https://doi.org/10.30743/11.v2i2.571.

Hamed, M. (2014). Conjunctions in Argumentative Writing of Libyan Tertiary Students. English Language Teaching, 7, (3), 108120. http://dx.doi.org/10.5539/elt.v7n3p 
Marzuki, S., \& Zainal, Z. (2004). Common errors produced by UTM students in report writing. Universiti Teknologi Malaysia (unpublished project report). University Teknologi Malaysia Repository.

Pandapatan, A. M. (2020). Analysis of the Subject-Verb Agreement Ability among Indonesian English Major Students as EFL Learners. Journal of English Language Studies, 5, 127-143. https://doi.org/https://jurnal.untirta.ac.id/index.php/JELS.

Quirk, R. \& Greenbaum, S. (1973). A University Grammar of English. Essex: Longman.

Salebi, M.Y. (2004). Saudi college students' perception of their errors in written English. Scientific Journal of King Faisal, 5, 209228.

Sufian, M. A., \& Harun, O. (2015). Errors in subject-verb agreement: A study based on Bangladeshi university students. Green University Review of Social Sciences, 2(2), 95-106.

Turkenik, C. (1998). Choices Writing Projects for Students of ESL. Cambridge: Cambridge University Press.

Wood, F. T. (1981). Current English Usage. London: The Macmillan Press Limited.

Wulandari, E. (2005). Error analysis on translation signals in narrative paragraphs made by fourth semester students of English Department Muhammadiyah University of Malang [Abstract] (Undergraduate thesis). University of Muhammadiyah Malang, Location.

Zawaherh, F. A. (2012). Applied Error Analysis of Written Production of English Essays of Tenth Grade Students in Ajloun Schools, Jordan. International Journal of Learning and Development, 2(2), 280. https://doi.org/10.5296/ijld.v2i2.1680. 